\title{
Expression of fibroblast growth factor-8 and regulation of cognate receptors, fibroblast growth factor receptor-3c and -4 , in bovine antral follicles
}

\author{
J Buratini Jr, A B Teixeira ${ }^{1}$, I B Costa ${ }^{2}$, V F Glapinski ${ }^{2}$, M G L Pinto ${ }^{1}$, I C Giometti ${ }^{1}$, \\ C M Barros ${ }^{2}, \mathrm{M} \mathrm{Cao}^{3}, \mathrm{E} \mathrm{S} \mathrm{Nicola}^{3}$ and C A Price ${ }^{3}$ \\ Departamento de Fisiologia, Instituto de Biociências, Universidade Estadual Paulista, Botucatu, São Paulo, Brazil, \\ ${ }^{1}$ Departamento de Reprodução Animal, Faculdade de Medicina Veterinária, Universidade Estadual Paulista, \\ Botucatu, São Paulo, Brazil, '²Departamento de Farmacologia, Instituto de Biociências, Universidade Estadual \\ Paulista, Botucatu, São Paulo, Brazil and ${ }^{3}$ Centre de Recherche en Reproduction Animale, Faculté de Médecine \\ Vétérinaire, Université de Montréal, St-Hyacinthe, Québec, Canada
}

Correspondence should be addressed to J Buratini; Email: buratini@ibb.unesp.br

\begin{abstract}
Paracrine cell signaling is believed to be important for ovarian follicle development, and a role for some members of the fibroblast growth factor (FGF) family has been suggested. In the present study, we tested the hypothesis that FGF-8 and its cognate receptors (FGFR3c and FGFR4) are expressed in bovine antral follicles. RT-PCR was used to analyze bovine Fgf8, Fgfr3c and Fgfr4 mRNA levels in oocytes, and granulosa and theca cells. Fgf8 expression was detected in oocytes and in granulosa and theca cells; this expression pattern differs from that reported in rodents. Granulosa and theca cells, but not oocytes, expressed Fgfr3c, and expression in granulosa cells increased significantly with follicle estradiol content, a major indicator of follicle health. Fgfr4 expression was restricted to theca cells in the follicle, and decreased significantly with increasing follicle size. To investigate the potential regulation of Fgfr3c expression in the bovine granulosa, cells were cultured in serum-free medium with FSH or IGF-I; gene expression was upregulated by FSH but not by IGF-I. The FSH-responsive and developmentally regulated patterns of $F g f r 3 c$ mRNA expression suggest that this receptor is a potential mediator of paracrine signaling to granulosa cells during antral follicle growth in cattle.

Reproduction (2005) 130 343-350
\end{abstract}

\section{Introduction}

Antral ovarian follicle growth in monovular species is regulated by a number of factors, the most well known of which are the gonadotropins. Follicles are considered to be follicle-stimulating hormone (FSH)-dependent until dominance occurs, after which they become luteinizing hormone-dependent (reviewed by Fortune et al. 2001, Ginther et al. 2001). It has also become clear that growth factors are key stimulatory/regulatory molecules. Several lines of evidence point to a critical role for members of the transforming growth factor- $\beta$ (TGF- $\beta$ ) superfamily, especially growth/differentiation factor 9 and bone morphogenetic protein 15 (reviewed by Gilchrist et al. 2004, Juengel et al. 2004, Shimasaki et al. 2004).

The fibroblast growth factor (FGF) family is emerging as a group of factors that are potentially important for follicle growth. For example, FGF-7 is expressed in theca cells, its receptor is expressed in granulosa cells (Parrott \& Skinner
1998, Berisha et al. 2004), and FGF-7 stimulated bovine granulosa cell proliferation and inhibited steroidogenesis (Parrott \& Skinner 1998). Another potentially interesting member of this family is FGF-8. Widely expressed in fetal tissues, this factor is predominantly expressed in the gonads of adult rodents and ruminants (MacArthur et al. 1995a, Buratini et al. 2005). Within the ovary, Fgfo gene expression occurs only in the oocyte in adult mice (Valve et al. 1997), which suggests a potential role in signaling of follicular cells by the oocyte.

There are five known FGF receptor (FGFR) genes (Kim et al. 2001, Sleeman et al. 2001), of which FGF-8 preferentially activates FGFR4 and the ' $\mathrm{C}$ ' splice form of FGFR3 (Ornitz et al. 1996). mRNAs encoding Fgfr4 or Fgfr3c were not consistently detected in the rodent ovary (Asakai et al. 1994, Puscheck et al. 1997), but were detected in bovine testis and ovary (Buratini et al. 2005).

In view of the very discrete expression pattern of the Fgf8 gene (i.e. in oocytes), and its role in tissue 
differentiation, it is of interest to determine if this growth factor may play a role in follicle development. The objectives of the present study were to determine if Fgf8 expression is restricted to oocytes in cattle, and to determine if the expression of Fgfr3C and Fgfr4 genes may be developmentally regulated in follicular somatic cells.

\section{Materials and Methods}

\section{Tissues}

Ovaries were obtained from an abattoir local to the São Paulo State University campus in Botucatu, and transported to the laboratory in saline on ice. Follicles greater than $5 \mathrm{~mm}$ in diameter were dissected from the ovaries, and follicular fluid was aspirated, centrifuged and frozen for steroid assay. The antral cavity was flushed repeatedly with cold saline and granulosa cells recovered by centrifugation at $1200 \mathrm{~g}$ for $1 \mathrm{~min}$, and pooled with the follicular fluid pellet. The remaining granulosa cells adhering to the follicle wall were removed by gently scraping with a blunt Pasteur pipette, and the theca layer removed with forceps and washed in saline by passing repeatedly through a $1 \mathrm{ml}$ syringe. The samples were collected into Trizol (Invitrogen, São Paulo, Brazil) and homogenized with a Polytron. Total RNA was extracted immediately according to the Trizol protocol.

Follicles were classified according to estradiol and progesterone content, and by size $(5-7,7-10$ and $>10 \mathrm{~mm}$ diameter; $n=12,19 \& 11$ respectively). Follicles containing less than $100 \mathrm{ng} / \mathrm{ml}$ progesterone were considered to be healthy and were grouped according to estradiol content into $<5 \mathrm{ng} / \mathrm{ml}(n=16), 5-20(n=10),>20-100$ $(n=10)$ and $>100 \mathrm{ng} / \mathrm{ml}(n=6)$ (based on Berisha et al. 2000). Follicles containing $\geq 100 \mathrm{ng} / \mathrm{ml}$ progesterone were classed as atretic, and contained mean estradiol concentrations of $0.06 \pm 0.02 \mathrm{ng} / \mathrm{ml}$. Cross-contamination of theca and granulosa cells was tested by detection of mRNA encoding cytochromes P450 aromatase (Cyp19) and $17 \beta$-hydroxylase (Cyp17) in each sample by PCR.

Cumulus-oocyte complexes were aspirated from antral follicles and cumulus cells removed from the oocyte by vortexing. Eleven pools of 50 oocytes and ten pools of 100 were collected, and RNA extracted with the RNeasy kit (Qiagen, São Paulo, Brazil).

\section{Cell culture}

The cell culture system was based on that described by Gutiérrez et al. (1997), with slight modifications (Silva \& Price 2000). All materials were obtained from Invitrogen except where otherwise stated. Briefly, bovine ovaries were collected from adult cows, irrespectively of stage of the estrous cycle, at an abattoir local to the University of Montreal Faculty of Veterinary Medicine and were transported to the laboratory in $\mathrm{PBS}$ at $35^{\circ} \mathrm{C}$ containing penicillin $(100 \mathrm{IU} / \mathrm{ml})$, streptomycin $(100 \mu \mathrm{g} / \mathrm{ml})$ and Fungizone
$(1 \mu \mathrm{g} / \mathrm{ml})$. Follicles ( $2-5 \mathrm{~mm}$ diameter) were dissected from the ovaries, and those with obvious signs of atresia (avascular theca, debris in antrum) were discarded. Cells were collected by repeatedly passing the follicle wall through a pipette, washed twice by centrifugation at $980 \mathrm{~g}$ for $20 \mathrm{~min}$ each, and suspended in $\alpha$-MEM, containing HEPES $(20 \mathrm{mM})$, sodium bicarbonate $(10 \mathrm{mM})$, sodium selenite $(4 \mathrm{ng} / \mathrm{ml})$, BSA $(0.1 \%$; Sigma-Aldrich Canada, Oakville, ON, Canada), penicillin $(100 \mathrm{IU} / \mathrm{ml})$, streptomycin $(100 \mu \mathrm{g} / \mathrm{ml})$, transferrin $(2.5 \mu \mathrm{g} / \mathrm{ml})$, non-essential amino acid mix $(1.1 \mathrm{mM})$, androstenedione $\left(10^{-7} \mathrm{M}\right.$ at start of culture, and $10^{-6} \mathrm{M}$ at each medium change) and insulin $(10 \mathrm{ng} / \mathrm{ml})$. Cell viability was estimated with $0.4 \%$ Trypan Blue stain. Cells were seeded into 24-well tissue culture plates (Corning Glass Works, Corning, NY, USA) at a density of $10^{6}$ cells/well in $1 \mathrm{ml}$ medium. Cultures were maintained at $37{ }^{\circ} \mathrm{C}$ in $5 \% \mathrm{CO}_{2}$ in air for 6 days, with $700 \mu \mathrm{l}$ medium being replaced every 2 days. Cells were stimulated with FSH (AFP-5332B; National Institute of Diabetes, Digestive and Kidney Diseases, Bethesda, MD, USA) or IGF-I analogue (Long R3; Sigma-Aldrich), at the doses given in Results. Medium samples were stored at $-20^{\circ} \mathrm{C}$ until the assay, and cells were collected in Trizol and stored at $-70^{\circ} \mathrm{C}$ until RNA extraction. Experiments were performed on three independent cultures.

\section{RT-PCR}

Primers for Fgf8 were designed based on alignment of published human and rodent sequences, and bovinespecific Fgfr3c and Fgfr4 primers were based on bovine sequences (Buratini et al. 2005). For the receptors, the sense primers were located in the third Ig-like domain, and the antisense primers were located in the second intracellular kinase domain (Table 1), thus spanning several exons. The Fgf8 sense and antisense primers were located in exons $1 \mathrm{D}$ and 3 respectively, allowing amplification of all known splice variants (MacArthur et al. 1995b).

FGFR expression was measured by semi-quantitative RT-PCR. For theca and granulosa cells, total RNA $(1 \mu \mathrm{g})$ was incubated with DNAse I (Invitrogen, São Paulo, Brazil) and reverse transcribed with SuperScript II (Invitrogen) and oligo-d(T) primer. The RNA yield from oocytes was too low to be accurately quantified by spectrometry, so $8 \mu \mathrm{l}$ aliquots of RNA were used in RT reactions.

For Fgfr4, target and glyceraldehyde-3-phosphate dehydrogenase (Gapd) genes were amplified in the same reaction to minimize errors due to pipetting and to simplify gel handling and documentation. PCR was performed on $0.5 \mu \mathrm{l} \mathrm{cDNA}$ in PCR mastermix containing $1.6 \mathrm{U}$ Taq DNA polymerase (Invitrogen), $0.4 \mu \mathrm{M} \mathrm{Fgfr4}$ and $0.06 \mu \mathrm{M}$ Gapd primers (Table 1), $0.2 \mathrm{mM}$ dNTPs and $1.5 \mathrm{mM}$ $\mathrm{MgCl}_{2}$ in a total volume of $25 \mu \mathrm{l}$. Samples were denatured for $3 \mathrm{~min}$ at $94^{\circ} \mathrm{C}$, followed by 28 cycles of denaturing at $94^{\circ} \mathrm{C}$ for $45 \mathrm{~s}$, annealing at $60^{\circ} \mathrm{C}$ for $45 \mathrm{~s}$ and extension at $70^{\circ} \mathrm{C}$ for $1 \mathrm{~min}$. 
Table 1 PCR primer data.

\begin{tabular}{|c|c|c|c|}
\hline Target & Sequence & Fragment size $(b p)$ & Reference \\
\hline Fgf8 & $\begin{array}{l}\text { F 5'-ACC AAC TCT ACA GCC GCA CCA G-3' } \\
\text { R 5'-GTA GTT GAG GAA CTC GAA GCG CAG-3' }\end{array}$ & 427 & AY183660 \\
\hline Fgfr $3 c$ & $\begin{array}{l}\text { F 5'-GGT GGT GCT GCC AGC T-3' } \\
\text { R 5'-TAA GTC CTT ATC CGT GGC GT-3' }\end{array}$ & 496 & Buratini et al. (2005) \\
\hline Fgfr 4 & $\begin{array}{l}\text { F 5'-AAG GCA GGT ACA CGG ACA TC-3' } \\
\text { R 5 5'-TAA GCA TCT TGA CAG CCA CG-3' }\end{array}$ & 426 & Buratini et al. (2005) \\
\hline Gapd & $\begin{array}{l}\text { F 5'-TGT TCC AGT ATG ATT CCA CC-3' } \\
\text { R 5 5'-TCC ACC ACC CTG TTG CTG-3' }\end{array}$ & 850 & Tsai et al. (1996) \\
\hline Cyp19 & $\begin{array}{l}\text { F 5'-TGC ATG GCA AGC TCT CC-3' } \\
\text { R 5 5'-TCC TTA TGT CTC TTT CAC C-3' }\end{array}$ & 373 & Z32741 \\
\hline Cур17 & $\begin{array}{l}\text { F 5'-GAA TGC CTT TGC CCT GTT CA-3' } \\
\text { R 5 5'-CGC GTT TGA ACA CAA CCC TT-3' }\end{array}$ & 330 & Lehmann et al. (2000) \\
\hline $\mathrm{H} 2 \mathrm{a}$ & $\begin{array}{l}\text { F 5'-GTC GTG GCA AGC AAG GAG-3' } \\
\text { R 5'-GAT CTC GGC CGT TAG GTA CTC-3' }\end{array}$ & 182 & Robert et al. (2002) \\
\hline
\end{tabular}

$\mathrm{F}=$ forward primer; $\mathrm{R}=$ reverse primer.

For Fgfr3c, PCR was performed separately for target and housekeeping genes, as multiplexing failed to provide linear amplification of discrete bands for this primer combination. The reaction contained $0.5 \mu \mathrm{l}$ (for Gapd) or $1 \mu \mathrm{l}$ (for Fgfr3c) cDNA in PCR mastermix containing 1.6 U Taq DNA polymerase (Invitrogen), $0.4 \mu \mathrm{M}$ Fgfr3c primers (Table 1) or $0.16 \mu \mathrm{M}$ Gapd primers, $0.2 \mathrm{mM}$ dNTPs and $1.5 \mathrm{mM} \mathrm{MgCl}_{2}$ in a total volume of $25 \mu \mathrm{l}$. Samples were denatured for $3 \mathrm{~min}$ at $94{ }^{\circ} \mathrm{C}$, followed by 24 (Gapd) or 33 (Fgfr3c) cycles of denaturing at $94^{\circ} \mathrm{C}$ for $30 \mathrm{~s}$, annealing for $45 \mathrm{~s}$ and extension at $70^{\circ} \mathrm{C}$ for $1 \mathrm{~min}$. Annealing temperatures were $65^{\circ} \mathrm{C}$ for Fgfr $3 \mathrm{C}$ and $60^{\circ} \mathrm{C}$ for Gapd.

To determine if Fgf8 expression is specific to oocytes in cattle, PCR was performed as described above on $1 \mu \mathrm{l}$ CDNA at $69.5^{\circ} \mathrm{C}$ annealing temperature for 34 (granulosa and theca) or 40 (oocytes) cycles.

All PCR reactions were performed with positive (fetal bovine brain, liver and ovary for Fgfr3C, Fgfr4 and Fgf8 respectively) and negative (water) controls. PCR products were separated on $1.5 \%$ agarose gels and stained with ethidium bromide, and specific bands quantified by densitometry (Image Gauge; Fuji Photo Film Co.).

Cycling conditions for semi-quantitative RT-PCR were optimized in preliminary experiments. The linear range of PCR for each target gene was first determined for $1 \mu \mathrm{g}$ RNA (Fig. 1), and the linearity of input amount of RNA was verified by performing RT-PCR with $0.5,1$ and $2 \mu \mathrm{g}$ RNA at the optimized cycle number for each gene (Fig. 1). To verify authenticity of the amplified DNA, amplicons from oocytes and theca and granulosa cell samples were excised from gels and sequenced (Department of Pharmacology, Federal University of São Paulo, São Paulo School of Medicine, São Paulo, Brazil).

To determine cross-contamination of theca and granulosa cells, PCR was performed on $0.5 \mu \mathrm{l}$ cDNA in the PCR mastermix described above but containing $0.4 \mu \mathrm{M}$ Cyp19 or Cyp17 primers (Table 1). Samples were amplified as above for 30 cycles at an annealing temperature of $58{ }^{\circ} \mathrm{C}$ for Cyp19 and $60^{\circ} \mathrm{C}$ for Cyp17. The presence of Cyp19 amplicons in theca samples or of Cyp17 in granulosa samples indicated cross-contamination, and such samples were discarded. Contamination of theca cells with granulosa cells is most likely as incomplete scraping of the follicle wall may leave adherent granulosa cells, and as 30 cycles of amplification are well beyond the linear range for granulosa cell RNA (Sahmi et al. 2004) we believe that we detected most cases of major contamination. Examples of non-contaminated samples are shown in Fig. 1A.

For analysis of gene expression in cultured granulosa cells, semi-quantitative RT-PCR was performed as described above, except that histone $\mathrm{H} 2 \mathrm{a}$ ( $\mathrm{H} 2 \mathrm{a})$ was used as the housekeeping gene. PCR was performed for 30 cycles at an annealing temperature of $55^{\circ} \mathrm{C}$.

\section{Steroid assays}

Estradiol and progesterone were assayed in follicular fluid using iodinated tracers and antibodies furnished in the $3 \mathrm{rd}$ Generation Estradiol RIA (DSL 39100) and the DSL-3400 Progesterone RIA kit (Diagnostic Systems Laboratories, Inc., Webster, TX, USA). The standard curves were prepared from crystalline steroids (Sigma Chemical Co.) in PBS-gelatin (0.02 M sodium phosphate, $0.15 \mathrm{M}$ sodium chloride, $0.1 \%$ gelatin, $0.01 \%$ sodium azide, $\mathrm{pH} 7.5)$. The assay protocols were as described in the kits, except that the estradiol antibody and tracer were each diluted 1:1 with PBS-gelatin before use, and the progesterone antibody and tracer were diluted 3:2 and 7:3 respectively. Follicular fluid samples were diluted in PBS-gelatin before assay. Intra- and inter-assay coefficients of variation were 7.4 and $13.5 \%$ respectively for estradiol, and 6.8 and $7 \%$ respectively for progesterone. The sensitivities of the assays were $0.05 \mathrm{ng} / \mathrm{ml}$ for estradiol (at 1:25 dilution of follicular fluid) and $0.2 \mathrm{ng} / \mathrm{ml}$ for progesterone (at 1:10 dilution).

\section{Statistics}

Target gene mRNA abundance was expressed relative to Gapd (for follicles) or H2a (granulosa cell cultures) mRNA (ratio of optical densities), and the data were transformed 
A

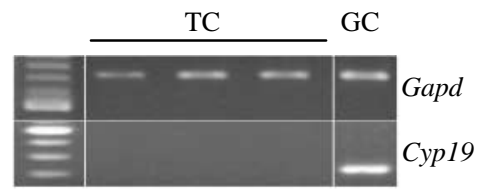

B
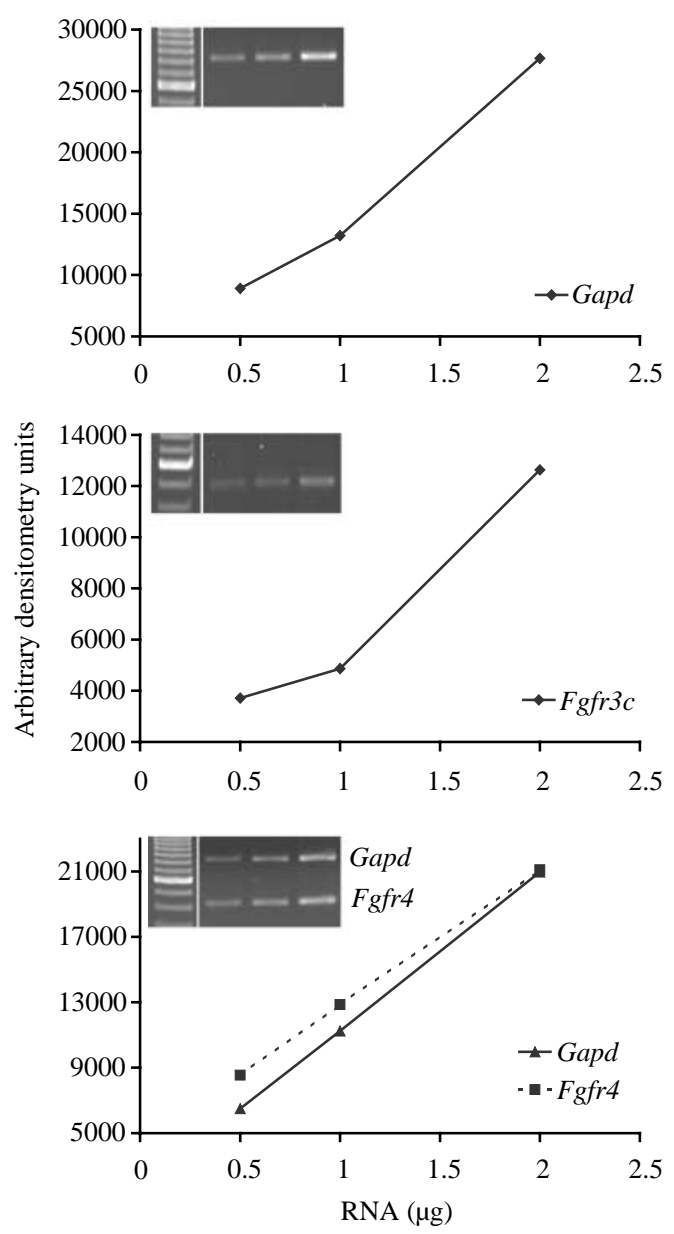
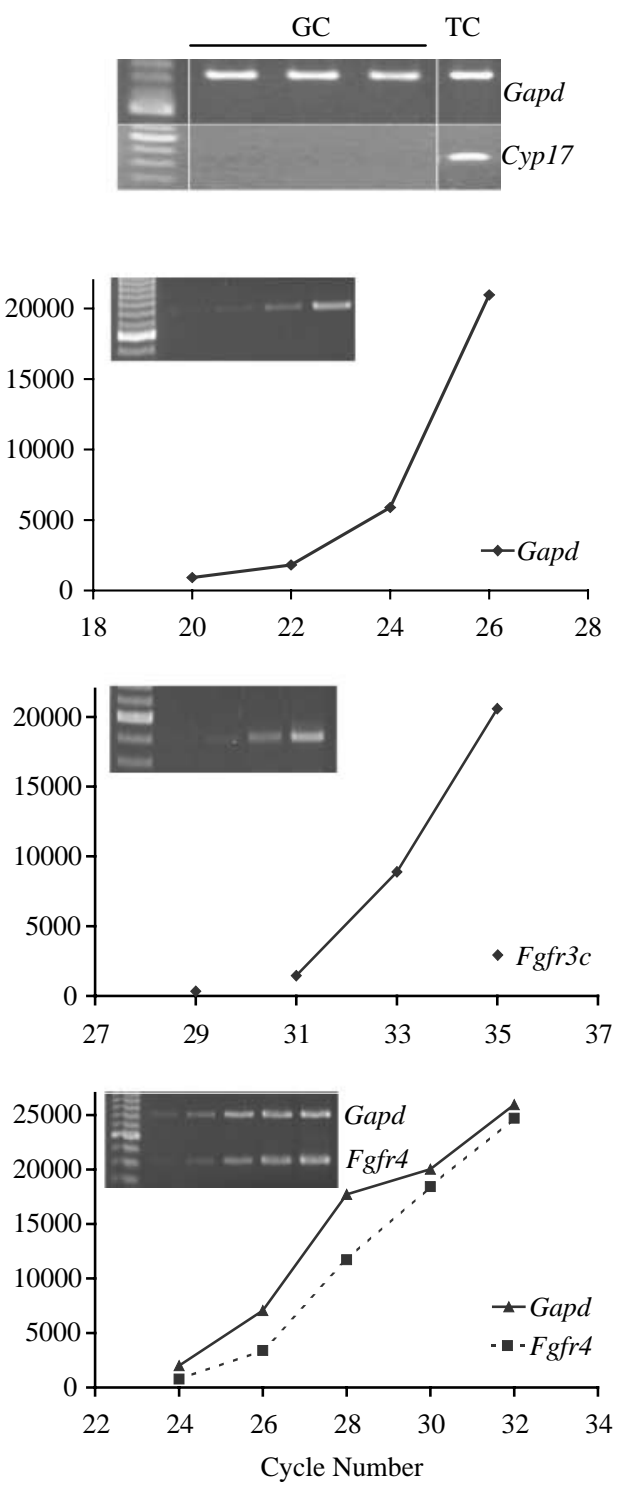

Figure 1 Validation of experimental techniques. (A) Agarose gel demonstrating purity of follicular cell types. Cyp19 expression was evident in a granulosa cell sample (GC) but not in three representative theca cells (TC), and Cyp17 was demonstrated in a theca sample but not in three representative granulosa samples. PCR was performed for 30 cycles. (B) Optimization of Fgfr3C and Fgfr4 semi-quantitative PCR, showing that amplified DNA is dependent on RNA amount (at optimized cycle number for each gene) and cycle number (with $1 \mu \mathrm{g}$ RNA). For analysis of Fgfr3C expression, target and housekeeping genes (Gapd) were amplified in separate reactions, whereas for Fgfr 4 the reaction with Gapd was performed in duplex. See Materials and Methods for cycling conditions. to logarithms where not normally distributed. ANOVA was used to test effects of follicle size and estradiol concentration on Fgfr3c and Fgfr4 mRNA levels, and the effect of FSH or IGF-I on granulosa cell Fgfr3c expression in vitro. For cell culture experiments, culture replicate was included as a random effect in the $F$-test. Means comparisons were performed by orthogonal contrasts. Linear correlations between gene expression and follicle estradiol content and size were assessed on untransformed data with Spearman's $r$ coefficient. Data are presented as means \pm S.E.M. Analyses were performed with JMP software (SAS Institute, Cary, NC, USA).

\section{Results}

Fgf8 mRNA was detected in pooled oocytes, and in granulosa and theca cells from individual follicles (Fig. 2A).
Amplified DNA was sequenced from oocyte samples and confirmed to be authentic Fgf8.

Fgfr3c mRNA was detected in both granulosa and theca cell layers (Fig. 3) but not in oocytes (Fig. 2B). Fgfr3C expression in granulosa cells from healthy follicles increased significantly with follicle estradiol content (Fig. 3; $P<0.05)$, and was significantly correlated with estradiol content $(r=0.66, n=47, P<0.001)$. When healthy follicles were classified by diameter, granulosa cell Fgfr3c expression increased with size (Fig. 3). Granulosa cell recovery from atretic follicles was very low, and gene expression was not measured. Thecal Fgfr3c mRNA levels were not significantly affected by estradiol content or diameter (atretic and healthy follicles).

Fgfr4 mRNA was detected in theca cells but not in granulosa cells (Fig. 4) or oocytes (Fig. 2B). Fgfr4 expression did not change with estradiol content of healthy follicles, but decreased significantly with increasing follicle size 

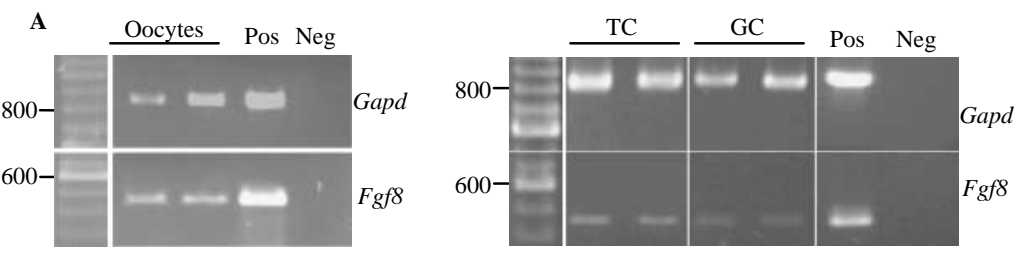

B

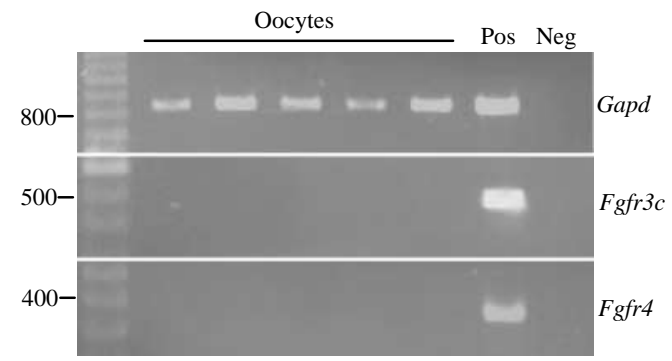

Figure 2 (A) Fgfo mRNA is expressed in bovine oocytes, granulosa and theca cells. These representative gels show PCR products for Fgf8 and Gapd amplified from two representative pools of 50 oocytes, and from granulosa (GC) and theca cell (TC) samples from two representative individual follicles. (B) Bovine oocytes did not test positive for Fgfr3C or FGFR4 mRNA. Data shown are of five pools of 50 oocytes each. Similar data were generated from pools of 100 oocytes (not shown). Positive (Pos; fetal ovary) and negative (Neg; water) PCR controls are also shown.
( $r=-0.56, n=47, \quad P<0.001)$. Follicles smaller than $8 \mathrm{~mm}$ expressed more $(P<0.05)$ Fgfr4 in theca cells compared with follicles $8-10 \mathrm{~mm}$, which in turn expressed more than follicles greater than $10 \mathrm{~mm}$ diameter (Fig. 4). In addition, no or barely detectable Fgfr4 gene expression was observed in theca cells from follicles containing more than $100 \mathrm{ng} / \mathrm{ml}$ progesterone.

As granulosa cell Fgfr3c mRNA abundance was affected by both follicle size and estradiol content, we determined if expression of this gene was under hormonal control. Granulosa cells were cultured for 6 days in non-luteinizing conditions (Sahmi et al. 2004). The expression of Fgfr3c increased $(P<0.05)$ upon addition of $1 \mathrm{ng} / \mathrm{ml} \mathrm{FSH}$, and did not increase further with higher doses of FSH (Fig. 5). In contrast, IGF-I resulted in a weak stimulation of Fgfr3c mRNA levels only at the highest dose used (Fig. 5).

\section{Discussion}

In rodents, the oocyte-specific expression of Fgf8 (Valve et al. 1997) suggests that this is a potential paracrine
A

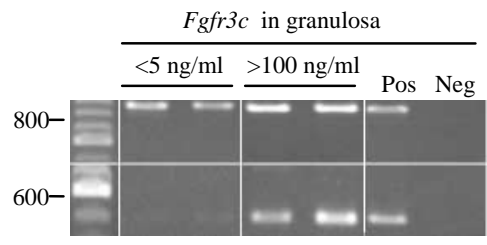

B

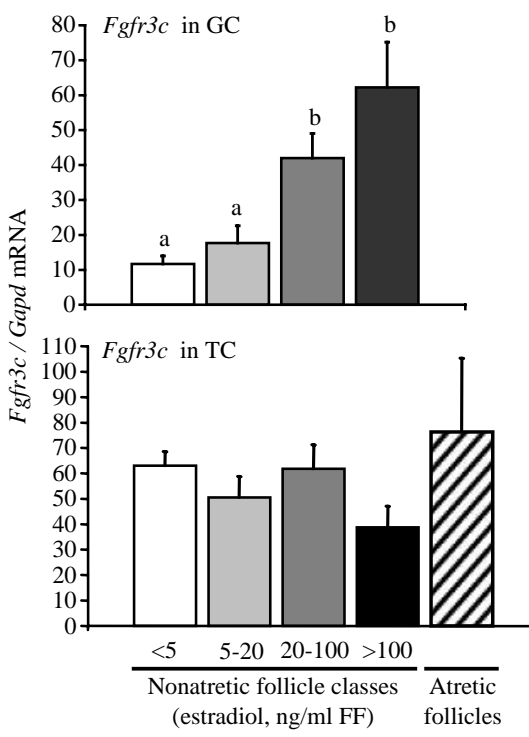

www.reproduction-online.org
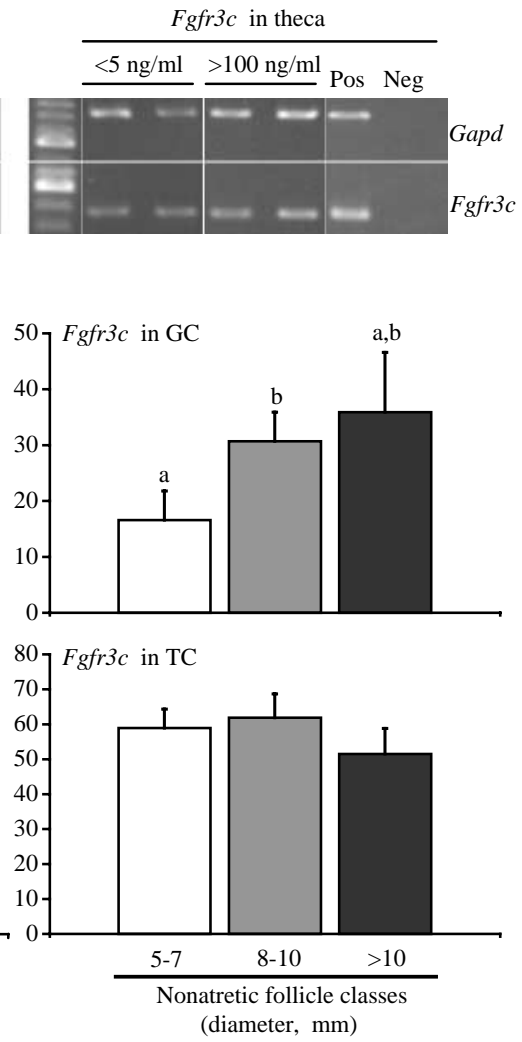

Figure 3 Developmental regulation of $\mathrm{Fgfr} 3 \mathrm{C}$ expression in bovine antral follicles. (A) Gels showing target and housekeeping (Gapd) PCR products in granulosa and in theca cells of two representative follicles with low $(<5 \mathrm{ng} / \mathrm{ml})$ and high $(>100 \mathrm{ng} / \mathrm{ml})$ estradiol concentrations in follicular fluid (FF). Positive (Pos; fetal brain) and negative (Neg; water) PCR controls are also shown. (B) Mean \pm S.E.M. relative Fgfr3c mRNA levels in granulosa (GC) and theca (TC) cells from non-atretic follicles classed according to FF estradiol content $(\mathrm{n}=16,10$ and 6 follicles, respectively) and from atretic follicles $(n=X)$, and from non-atretic follicles grouped by diameter $(n=12,19$ and 11 follicles, respectively). Means with different letters are significantly different $(P<0.05)$. Data for atretic follicles were derived from theca samples only, as insufficient granulosa cell RNA was recovered from atretic follicles. 
A

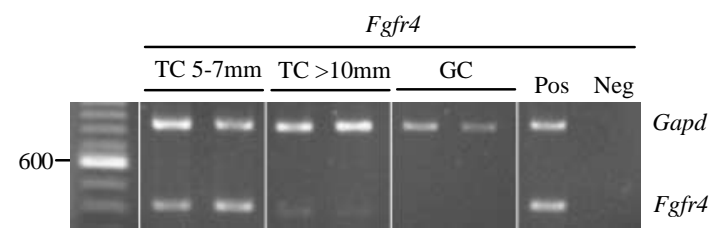

B
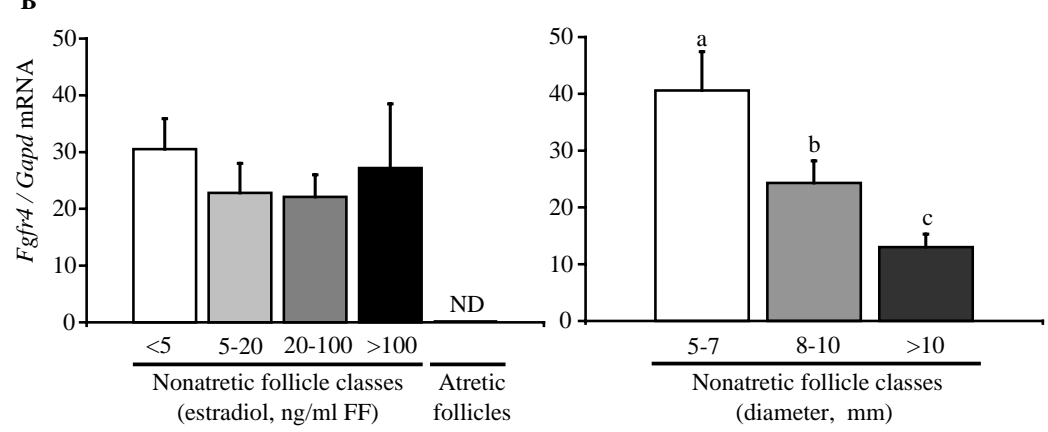

Figure 4 Effect of follicle size but not estradiol content on expression of Fgfr 4 in thecal cells of bovine antral follicles. (A) Gels showing target and housekeeping (Gapd) PCR products in theca cells (TC) of two representative medium sized $(5-7 \mathrm{~mm}$ diameter) and two large ( $>10 \mathrm{~mm}$ diameter) follicles. Fgfr 4 was not amplified from granulosa cells (GC). Positive (Pos; fetal liver) and negative (Neg; water) PCR controls are also shown. (B) Mean \pm S.E.M. relative Fgfr4 mRNA levels in theca cells from non-atretic follicles classed according to follicular fluid (FF) estradiol content ( $n=16,10$ and 6 follicles, respectively) and from atretic follicles $(n=X)$, and from non-atretic follicles grouped by diameter $(\mathrm{n}=12,19$ and 11 follicles, respectively). Means with different letters are significantly different $(P<0.05)$. molecule signaling between the oocyte and follicle somatic cells. In this report we provide evidence that Fgf8 is expressed in theca and granulosa cells as well as in oocytes in cattle. Owing to the low amount of RNA recovered from the oocyte pools used here, we could not determine the amount of RNA used in the reverse transcription. Accordingly, we increased PCR cycle number for Fgf8 and the housekeeping gene Gapd, to produce a Gapd PCR product of intensity roughly equivalent to that observed in granulosa and theca cells. Assuming that Gapd mRNA levels are not dramatically different between the cell types, we conclude that Fgf8 expression is not higher in oocytes compared with granulosa and theca cells in cattle, and therefore may not be an important oocyte-specific signaling molecule in ruminants. There are other discrepancies in Fgf8 localization between species, as expression was not detected in human ovarian cortex by PCR (Valve et al. 2000), but the protein was found in human corpus luteum by immunohistochemistry (Zammit et al. 2002).

On the assumption of Fgf8 expression in oocytes, we hypothesized that the principal FGF-8 receptors (FGFR3c and FGFR4) would be expressed in granulosa and/or theca cells. Very little is known about Fgfr3c gene expression in the ovary. A pan-Fgfr3 riboprobe that did not distinguish the ' $b$ ' and ' $c$ ' splice variants did not detect Fgfr 3 mRNA in mouse ovary by in situ hybridization (Puscheck et al. 1997), and Fgfr3C expression was not detected in the human ovary by PCR (Valve et al. 2000). A pan-FGFR3 antibody localized protein to the granulosa layer in mice

A

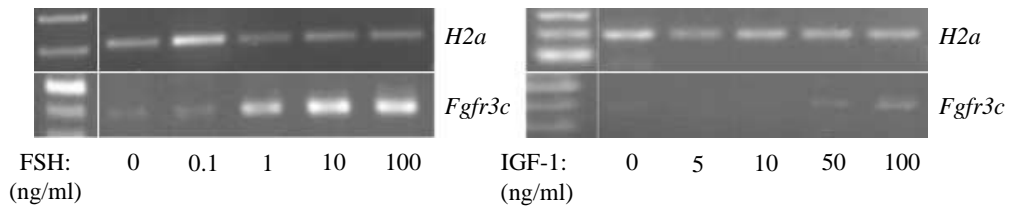

B
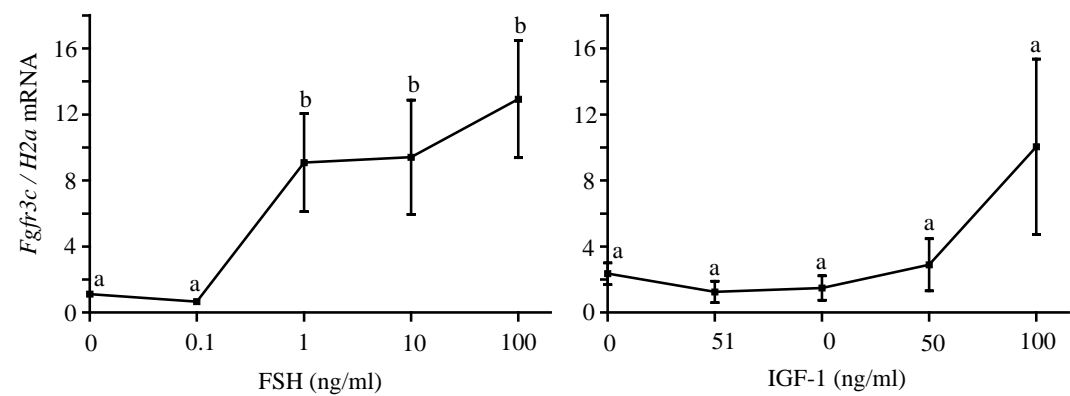

Figure 5 Regulation of Fgfr3c expression in granulosa cells by FSH in vitro. (A) Representative gels and (B) mean \pm S.E.M. relative Fgfr3c mRNA levels in granulosa cells cultured for 6 days in serum-free medium with the stated doses of FSH or IGF-I. Expression of $H 2 a$ was used as an internal control in RT-PCR. Means with different letters are significantly different $(P<0.05)$. Data are derived from three independent experiments $(\mathrm{n}=3)$. 
(Amsterdam et al. 2001). In the present study, we demonstrate Fgfr3c expression in granulosa and theca cells of bovine antral follicles. Whereas the expression of Fgfr $3 \mathrm{C}$ in theca cells was relatively stable, expression increased during follicle development (based on follicle size and estradiol content) in granulosa cells, consistent with a role for FGFR3c signaling during antral follicle growth. Functional studies were performed to determine if Fgfr3C expression is regulated, and the data show that Fgfr $3 \mathrm{C}$ expression is clearly increased by FSH. It is of relevance that near maximal levels of Fgfr3c expression were observed at physiological doses of FSH, as observed also for Cyp19 and 17ß-hydroxysteroid dehydrogenase genes (Sahmi et al. 2004). Certain FSH-responsive endpoints are also stimulated by IGF-I, including steroid and inhibin-A secretion and Cyp19 expression (Gutiérrez et al. 1997, Glister et al. 2001, Spicer et al. 2002); however, the present data clearly demonstrate that Fgfr3C expression is not under IGF-I control. The physiological importance of Fgfr3C regulation by $\mathrm{FSH}$ in granulosa cells remains to be clarified, but as regulation of Fgfr3c expression by estradiol has been demonstrated in the human endometrium (Wing et al. 2003), changes in receptor expression may play a role in regulating signal transduction.

Fgfr 4 gene expression has previously been detected in mouse follicles and human ovaries (Puscheck et al. 1997, Valve et al. 2000). In the present study, Fgfr4 expression was localized specifically to the theca cell layer, which is in contrast to data from the mouse showing expression only in granulosa cells (Puscheck et al. 1997). Fgfr4 gene expression was highest in small follicles and decreased as follicles reached the size of dominant follicles, suggesting a role for FGFR4 signaling in theca cells during early growth of antral follicles. It is interesting to note that Fgfr4 expression was reduced to very low or undetectable levels in the theca of atretic follicles, suggesting that this gene is downregulated during atresia. The present studies are unavoidably limited by the lack of antibodies available for protein detection. No isoform-specific antibodies are available for FGFR3, and commercial antibodies against FGFR4 do not adequately recognize protein in bovine tissues (Buratini et al. 2005).

Which ligand(s) might activate FGFR3c and FGFR4 in follicles remains to be clarified. FGF-1, -2, -4, -8, -9 and -13 efficiently activate FGFR3c and -4 (Ornitz et al. 1996, Greene et al. 1998). In cattle, Fgf1 and Fgf2 expression was predominantly localized to theca cells (Berisha et al. 2004), and Fgf2 expression increased with estradiol content (Berisha et al. 2004) as did the expression of Fgfr3C in granulosa cells in the present study. FGF2 binding is not very specific, in the sense that it activates receptors 1, 2c, 3c and 4 (Ornitz et al. 1996). Fgfr1 and Fgfr2c appear not to be developmentally regulated in bovine follicles (Berisha et al. 2004), whereas Fgfr3c is (present report). The actions of FGFs at different stages of follicle growth clearly warrant further study.
Taken together, the present data suggest that signaling pathways activated by FGFR3c and FGFR4 play roles during follicle growth. Specific signaling may be modulated by changes in ligand or receptor levels. The present data clearly demonstrate that Fgfr3c gene expression increases in healthy follicles as follicle estradiol content increases, and Fgfr3C expression is upregulated by $\mathrm{FSH}$. This important observation suggests that FSH may sensitize granulosa cells to one or more FGFs during early growth of the antral follicle, and may permit continued growth of the follicle in the low-FSH environment that follows follicle deviation (see Fortune et al. 2001, Ginther et al. 2001).

\section{Acknowledgements}

We thank Dr M C Avellar (Universidade Federal de São Paulo-Escola Paulista de Medicina) and Dr J F Garcia (Universidade Estadual Paulista, Araçatuba) for sequencing amplicons of target genes, Dr P R Ramos (Universidade Estadual Paulista, Botucatu) and Dr F V Meirelles (Universidade de São Paulo, Pirassununga) for assistance with image analysis, and A C Castilho and P B Andrade for technical assistance. This work was supported by FAPESP, Brazil (J B) and NSERC, Canada (C A P). The authors declare that there is no conflict of interest that would prejudice the impartiality of this scientific work.

\section{References}

Amsterdam A, Kannan K, Givol D, Yoshida Y, Tajima K \& Dantes A 2001 Apoptosis of granulosa cells and female infertility in achondroplastic mice expressing mutant fibroblast growth factor receptor 3G374R. Molecular Endocrinology 15 1610-1623.

Asakai R, Song SY, Itoh N, Yamakuni T, Tamura K \& Okamoto R 1994 Differential gene expression of fibroblast growth factor receptor isoforms in rat ovary. Molecular and Cellular Endocrinology 104 75-80.

Berisha B, Schams D, Kosmann M, Amselgruber W \& Einspanier R 2000 Expression and localisation of vascular endothelial growth factor and basic fibroblast growth factor during the final growth of bovine ovarian follicles. Journal of Endocrinology 167 $371-382$.

Berisha B, Sinowatz F \& Schams D 2004 Expression and localization of fibroblast growth factor (FGF) family members during the final growth of bovine ovarian follicles. Molecular Reproduction and Development 67 162-171.

Buratini J, Glapinski VF, Giometti IC, Teixeira AB, Avellar MCW, Barros CM \& Price CA 2005 Expression of fibroblast growth factor8 and its cognate receptors, fibroblast growth factor receptor (FGFR)-3c and -4, in fetal bovine preantral follicles. Molecular Reproduction and Development 70 255-261.

Fortune JE, Rivera GM, Evans AC \& Turzillo AM 2001 Differentiation of dominant versus subordinate follicles in cattle. Biology of Reproduction 65 648-654.

Gilchrist RB, Ritter LJ \& Armstrong DT 2004 Oocyte-somatic cell interactions during follicle development in mammals. Animal Reproduction Science 82-83 431-446.

Ginther OJ, Beg MA, Bergfelt DR, Donadeu FX \& Kot K 2001 Follicle selection in monovular species. Biology of Reproduction $\mathbf{6 5}$ 638-647.

Glister C, Tannetta DS, Groome NP \& Knight PG 2001 Interactions between follicle-stimulating hormone and growth factors in modulating secretion of steroids and inhibin-related peptides by 
nonluteinized bovine granulosa cells. Biology of Reproduction 65 1020-1028.

Greene JM, Li YL, Yourey PA, Gruber J, Carter KC, Shell BK, Dillon PA, Florence C, Duan DR, Blunt A, Ornitz DM, Ruben SM \& Alderson RF 1998 Identification and characterization of a novel member of the fibroblast growth factor family. European Journal of Neuroscience 10 1911-1925.

Gutiérrez CG, Campbell BK \& Webb R 1997 Development of a long-term bovine granulosa cell culture system: induction and maintenance of estradiol production, response to follicle-stimulating hormone, and morphological characteristics. Biology of Reproduction 56 608-616.

Juengel JL, Bodensteiner KJ, Heath DA, Hudson NL, Moeller CL, Smith P, Galloway SM, Davis GH, Sawyer HR \& McNatty KP, 2004 Physiology of GDF9 and BMP15 signalling molecules. Animal Reproduction Science 82-83 447-460.

Kim I, Moon S, Yu K, Kim U \& Koh GY 2001 A novel fibroblast growth factor receptor-5 preferentially expressed in the pancreas. Biochimica et Biophysica Acta 1518 152-156.

Lehmann T, Biernacka-Lukanty J \& Trzeciak WH 2000 Expression of three negative regulators of CYP17 gene transcription in adrenocortical cells. Endocrine Research 26 1019-1026.

MacArthur CA, Shankar DB \& Shackleford GM 1995a Fgf-8, activated by proviral insertion, cooperates with the $\mathrm{Wnt}-1$ transgene in murine mammary tumorigenesis. Journal of Virology 69 2501-2507.

MacArthur CA, Lawshe A, Xu J, Santos-Ocampo S, Heikinheimo M, Chellaiah AT \& Ornitz DM 1995b FGF-8 isoforms activate receptor splice forms that are expressed in mesenchymal regions of mouse development. Development 121 3603-3613.

Ornitz DM, Xu J, Colvin JS, McEwen DG, MacArthur CA, Coulier F, Gao G \& Goldfarb M 1996 Receptor specificity of the fibroblast growth factor family. Journal of Biological Chemistry 271 $15292-15297$.

Parrott JA \& Skinner MK 1998 Developmental and hormonal regulation of hepatocyte growth factor expression and action in the bovine ovarian follicle. Endocrinology 139 228-235.

Puscheck EE, Patel Y \& Rappolee DA 1997 Fibroblast growth factor receptor (FGFR)-4, but not FGFR-3 is expressed in the pregnant ovary. Molecular and Cellular Endocrinology 132 169-176.

Robert C, McGraw S, Massicotte L, Pravetoni M, Gandolfi F \& Sirard MA 2002 Quantification of housekeeping transcript levels during the development of bovine preimplantation embryos. Biology of Reproduction 67 1465-1472.

Sahmi M, Nicola ES, Silva JM \& Price CA 2004 Expression of $17 \beta-$ and $3 \beta$-hydroxysteroid dehydrogenases and steroidogenic acute regulatory protein in non-luteinizing bovine granulosa cells in vitro. Molecular and Cellular Endocrinology 223 43-54.
Shimasaki S, Moore RK, Otsuka F \& Erickson GF 2004 The bone morphogenetic protein system in mammalian reproduction. Endocrine Reviews $2572-101$.

Silva JM \& Price CA 2000 Effect of follicle-stimulating hormone on steroid secretion and messenger ribonucleic acids encoding cytochromes P450 aromatase and cholesterol side-chain cleavage in bovine granulosa cells in vitro. Biology of Reproduction 62 186-191.

Sleeman M, Fraser J, McDonald M, Yuan S, White D, Grandison P, Kumble K, Watson JD \& Murison JG 2001 Identification of a new fibroblast growth factor receptor, FGFR5. Gene 271 171-182.

Spicer LJ, Chamberlain CS \& Maciel SM 2002 Influence of gonadotropins on insulin- and insulin-like growth factor-I (IGF-I)-induced steroid production by bovine granulosa cells. Domestic Animal Endocrinology 22 237-254.

Tsai SJ, Wiltbank MC \& Bodensteiner KJ 1996 Distinct mechanisms regulate induction of messenger ribonucleic acid for prostaglandin (PG) G/H synthase-2, PGE (EP3) receptor, and PGF2 alpha receptor in bovine preovulatory follicles. Endocrinology 137 3348-3355.

Valve E, Penttila TL, Paranko J \& Harkonen P 1997 FGF-8 is expressed during specific phases of rodent oocyte and spermatogonium development. Biochemical and Biophysical Research Communications 232 173-177.

Valve E, Martikainen P, Seppanen J, Oksjoki S, Hinkka S, Anttila L, Grenman S, Klemi P \& Härkönen P 2000 Expression of fibroblast growth factor (FGF)-8 isoforms and FGF receptors in human ovarian tumors. International Journal of Cancer 88 718-725.

Wing LY, Chuang PC, Wu MH, Chen HM \& Tsai SJ 2003 Expression and mitogenic effect of fibroblast growth factor-9 in human endometriotic implant is regulated by aberrant production of estrogen. Journal of Clinical Endocrinology and Metabolism 88 5547-5554.

Zammit C, Coope R, Gomm JJ, Shousha S, Johnston CL \& Coombes RC 2002 Fibroblast growth factor 8 is expressed at higher levels in lactating human breast and in breast cancer. British Journal of Cancer 86 1097-1103.

Received 5 January 2005

First decision 1 March 2005

Revised manuscript received 30 March 2005

Accepted 23 May 2005 